\title{
Investigating the U.S. Oil-Macroeconomy Nexus using Rolling Impulse Responses
}

\author{
MARC GRONWALD
}

CESIFO WORKING PAPER NO. 2702

CAtegory 6: Fiscal Policy, Macroeconomics and Growth

JULY 2009

\footnotetext{
An electronic version of the paper may be downloaded

- from the SSRN website: Www.SSRN.com

- from the RePEc website: $\quad$ www.RePEc.org

- from the CESifo website: www.CESifo-group.org/wp
} 


\title{
Investigating the U.S. Oil-Macroeconomy Nexus using Rolling Impulse Responses
}

\begin{abstract}
This paper is concerned with the apparent change in the U.S. oil price-macroeconomy relationship. It is investigated to what extent this change can be accounted for by the large oil price surges witnessed in the 1970s. The innovative approach of rolling impulse responses is applied and both the aggregate and the industry-level is considered. It is found that the first oil crisis has an "persistent" effect in the sense that this incident still dominates long-run results and superimposes both subsample and industry-specifics. The results, furthermore, suggest that the Great Moderation can essentially be explained by the non-occurrence of large oil shocks after the mid 1980s and that oil is less important for the economy than many researchers still believe.
\end{abstract}

JEL Code: C32, C63, E32.

Keywords: oil price, vector autoregressions, rolling impulse responses, Great Moderation.

Marc Gronwald
Ifo Institute for Economic Research at the
University of Munich
Poschingerstrasse 5
81679 Munich
Germany
gronwald@ifo.de

March 2009 


\section{InTRODUCTION}

An enormous amount of papers investigate the macroeconomic consequences of oil price shocks, predominantly for the case of the U.S. economy. This line of research has its genesis in Hamilton's (1983) seminal paper, which emphasizes that "all but one of the U.S. recessions since World War II have been preceded $[. .$.$] by a dramatic increase in the price of crude petroleum",$ and consists of empirical as well as theoretical papers.

On the empirical front the VAR modeling approach popularized by Sims (1980) has been frequently applied [Burbidge and Harrison, 1984; Peersman and Van Robays, 2009]. The relationship between the oil price and economic activity, however, turned out to be more sophisticated than it originally appeared to be. Bernanke et al.'s (1997, p.94) statement that "it is surprisingly difficult to find an indicator of oil price shocks that produces the expected responses of macroeconomic and policy variables in a VAR setting" typifies the discussion on how to correctly specify the oil price. ${ }^{1}$ Barsky and Kilian (2004) argue that oil is less important for the economy than many researches believe. What is more, Kilian (2008) shows that not just oil price behavior itself, but also the underlying cause of oil price shocks changed over time. There are also theoretical contributions that address the macroeconomics of the oil price, see e.g. Hamilton (1988) and Rotemberg and Woodford (1995). ${ }^{2}$

This paper is motivated as follows. There is, first, evidence that the observed impact of oil price shocks can largely be accounted for by the first and second oil crises as well as the 1990/91 Gulf War [Gronwald, 2008]. Second, a number of empirical papers emphasize the apparent change in

\footnotetext{
${ }^{1}$ Various so-called non-linear oil price specifications have been proposed in this literature. The most popular ones by Lee et al. (1995) and Hamilton (1996) promote the view that the volatility environment in which an oil price increase takes place is crucial. Jimenez-Rodriguez and Sanchez (2005) and Gronwald (2008) are among the most recent papers that deal with this issue; Hamilton (2003) provides further evidence of the nonlinear character of the oil price-macro relationship. Bernanke's (1983) and Lilien's (1988) theoretical frameworks frequently serve as motivation for these new oil price specifications. Other papers such as Hooker (1996) address the issue of whether the relationship is structurally stable.

${ }^{2}$ Jones et al. (2004) and Rogoff (2007) provide useful summaries of these research efforts.
} 
the relationship between the oil price and economic activity [Blanchard and Gali, 2007; Edelstein and Kilian, 2007; Herrera and Pesavento, 2007]. Third, investigating the effect of oil shocks on the industry-level rather than just the aggregate level currently receives growing attention [Lee and Ni, 2002; Herrera, 2006; Jimenez-Rodriguez, 2007]. ${ }^{3}$

This paper deals, for the case of the U.S. economy, with the following two issues: it, first, further investigates the apparent change in the oil pricemacroeconomy relationship on both the aggregate an the industry-level. The question to what extent this change can be accounted for by the large oil price increases discussed in Gronwald (2008) forms the core of this paper. Second, the paper tries to shed further light on the factors explaining the Great Moderation firstly mentioned in Kim and Nelson (1999) and McConnell and Perez-Quiros (2000).

Different empirical strategies have been pursued in order to account for this change. While Baumeister and Peersman (2008) employ an econometric method that allows the parameters to be time-varying, various other papers including Hooker (1996) and Herrera and Pesavento (2008) consider disjunct subsamples. This paper, in contrast, applies the rolling impulse response technique put forward by Blanchard and Gali (2007). They argue that "some of the potential explanations for the change in the effects of oil price shocks are more likely to have been associated with a more gradual variation over time" (p.31); but, however, restrict themselves to bivariate rolling VARs. This paper uses monthly industrial production data rather than quarterly GDP data as indicator of economic activity. The larger number of observations allows the estimation of rolling impulse responses for higher dimensional VARs, which are usually considered in the oil price literature. This innovative way of using a standard approach, furthermore, facilitates comparability of the results to those of other papers and does not involve sophisticated structural break testing.

The following findings can be drawn from this study: first, the change in

\footnotetext{
${ }^{3}$ Bohi's (1989) industry-level study needs also to be mentioned here; which, however, does not employ a VAR modeling approach. Kilian and Park (2008) also study industrylevel effects of oil price shocks, but focus on stock market returns rather than production.
} 
the oil price macroeconomy relationship appears to be abrupt rather than gradual. Second, the first oil crisis 1973/74 drives main characteristics of the full sample results and superimposes both subsample and industry-specific results. Third, there is evidence that the so-called "good luck" aspect of the Great Moderation can be accounted for by the non-occurrence of large oil shocks. This last finding reinforces views promoted by Summers (2005) and Nakov and Pescatori (2008).

The remainder of the paper is organized as follows: Section 2 describes the model setup and the data, Sections 3 and 4 present the estimation results as well as a discussion of which. Section 5, finally, offers some concluding remarks.

\section{Empirical Setup And Data}

This paper's empirical set-up is borrowed from Lee and Ni (2002). Initially, a macro-VAR (log of total industrial production, the log of the consumer price index, the three-month treasury bill rate, the yield for government bonds maturing in more than 10 years, the log of M2 money supply and Hamilton's (1996) oil price measure) is used in order to study the effect of oil price shocks at the aggregate level. ${ }^{4}$ As a second step, industry-level effects of oil price shocks are studied by complementing this macro-block by production data of one out of ten two-digit and one three-digit SIC industries, also taken in logs. Thus, one six-variable and 11 seven-variable VARs with 12 lags of the variables in each VAR are estimated. For the macro-VARs, monthly data from 1962:02 to 2008:11 and for the industry-level-VARs data from 1962:02 to $2002: 10$ is used. $^{5}$ The Cholesky identification strategy is applied and

\footnotetext{
${ }^{4}$ Hamilton's (1996) oil price specification measures whether an oil price increase is larger than decreases witnessed in the preceding 12 months. The real oil price is used, obtained by deflating the West Texas Intermediate Spot Price by the U.S. Producer Price Index.

${ }^{5}$ Data are drawn from the following sources: Federal Reserve (industrial production, short-term interest rate), IMF-IFS (long-term interest rate), the U.S. Bureau of Labour Statistics (Consumer and Producer Prices), the Conference Board (M2), and the Federal Reserve Bank of St.Louis (oil price). Industry-level data are also drawn from the Federal Reserve. Due to the 1997 SIC/NAICS replacement, no industry-level data-set with both more recent data and a sufficient coverage of the $1960 \mathrm{~s} / 1970 \mathrm{~s}$ is available. The data used here is the most appropriate one for this study's focus on the particular role of the
} 
impulse responses are estimated in order to visualize the oil shocks effects, the significance of which is assessed using asymptotic standard error bands. ${ }^{6}$ Each rolling VAR subsample consists of 200 observations; the first subsample runs from 1962:02 to 1978:09; the last macro-one from 1992:04 to 2008:11 and the last industry-level-one from 1988:04 to 2002:10. ${ }^{7}$

Having outlined this paper's modeling approach, the industries considered in this paper are now discussed. Among those industries are usual suspects such as motor vehicle production and the chemical industry, but also ones usually not considered being energy intensive such as the tobacco industry, see Table 1. The table, furthermore, provides information regarding the development of the industries' oil intensities from 1972 to 2002, measured following Lee and Ni's (2002) proposal of using the cost of oil and natural gas for each dollar of sale. It is not surprising that petroleum refineries and the chemical industry have the largest portion, while e.g. the tobacco industry is found at the bottom of the table. Taking off at fairly low values in 1972, the 1970s oil crises leads to a substantial increase in all industries' portions. From the early 1990s on the figures decline again. It is, furthermore, evident that, apart from the rise of the rubber industry, there are no appreciable changes in the order of the industries.

Lee and Ni (2002) emphasize that this measure of oil intensity is advantageous to using broader energy-intensity measures as the latter do not take into account that some energy-intensive industries have coal as the main source of energy. Bohi $(1989,1991)$, however, makes use of such broader

1970s oil price increases. Furthermore, other recent studies such as Herrera (2006) and Jimenez-Rodriguez (2007) use periods of observations that end even earlier.

${ }^{6}$ The ordering of the variables in the six-variable VAR is industrial production, consumer price index, short-term interest rate, long-term interest rate, money supply and the oil price; the industry in each seven-variable VAR is ordered after industrial production. Thus, it is allowed for contemporaneous reactions of the oil price to the other variables. The results, however, are robust to changes in this ordering, in particular to more exogenous rankings of the oil price variable. The Appendix provides a number of alternative specifications. Using Monte Carlo standard error bands as well as bootstrap confidence bands leaves the results generally unchanged. The detailed results can be obtained from the author upon request.

${ }^{7}$ The last few industry-level subsamples, however, consist of slightly fewer observations. They are included in order to have a sufficient amount of samples beginning after the 1986 break in the oil price series. 


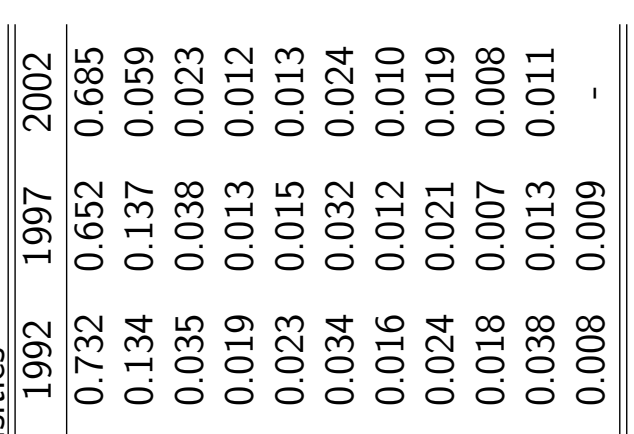

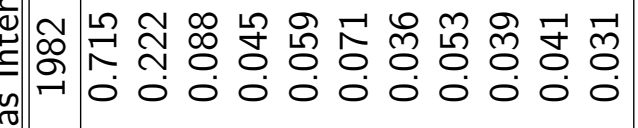

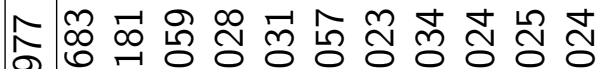

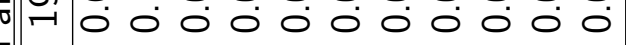

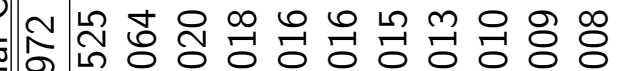
ำ 으

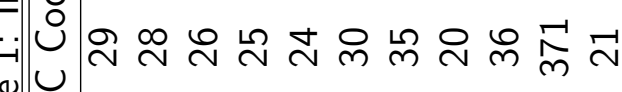

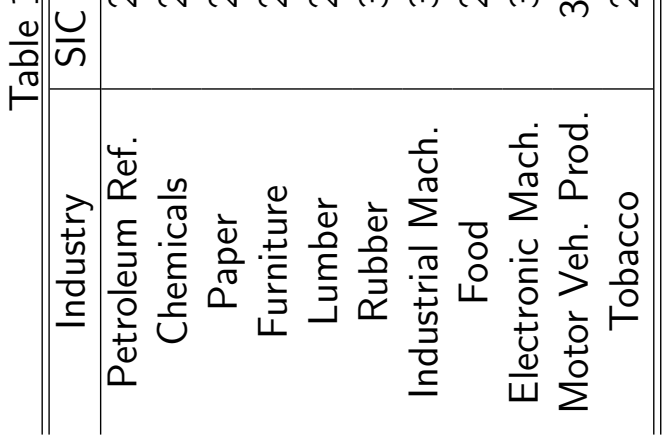


measures and obtains a similar ranking of the industries. ${ }^{8}$

The following two sections now present this paper's empirical results, beginning with those of the full sample in Section 3.

\section{Full Sample Results}

As a point of departure, the effect of oil price shocks on total industrial production as well as the 11 industries is investigated using the full sample. The results of this exercise are presented in Figure 1. The top-left panel depicts the response of total industrial production to an oil price shock together with the analytical two-standard-error bands. Three characteristics of the response are to be accentuated: first, there is no initial significant response; second, 10-15 months after the shock a clear negative significant response emerges; followed by, third, a relaxation of the effect. This result is very similar to that of Lee and Ni (2002) and, furthermore, generally in line with the literature, which finds the strongest negative impact about 1 year after an oil shock's occurrence [Jimenez-Rodriguez and Sanchez, 2005; Gronwald, 2008]. Figure 1's remaining panels report the response of the 11 industries to an oil shock, obtained from applying the strategy outlined above. It is apparent that the response's patterns across industries are fairly homogeneous and are, moreover, also similar to the characteristic response of total industrial production. In particular, the negative responses' peak 10 to 15 months after the shock reappears. However, only for industries such as paper, lumber, and rubber a significant impact is apparent - a result anticipated by Section 2's discussion of the industries' oil intensities. Those industries are ranked in upper regions of Table 1; "bottom-table" industries such as tobacco and electronic machinery are not significantly affected by an oil price shock. ${ }^{9}$

The purpose of this full sample exercise is to get a first impression of

\footnotetext{
${ }^{8}$ The same applies to using energy intensities provided by the U.S. Department of Energy. It should be noted, however, that measuring industrial energy intensity is still subject of discussions; see Freeman et al. (1997) and Liu and Ang (2007).

${ }^{9}$ Lee and $\mathrm{Ni}$ (2002) use a different set of industries and find a negative significant response for all industries but petroleum refineries. This is possibly due to the fact that they use a lower significance level.
} 
Figure 1: Full Sample Impulse Responses
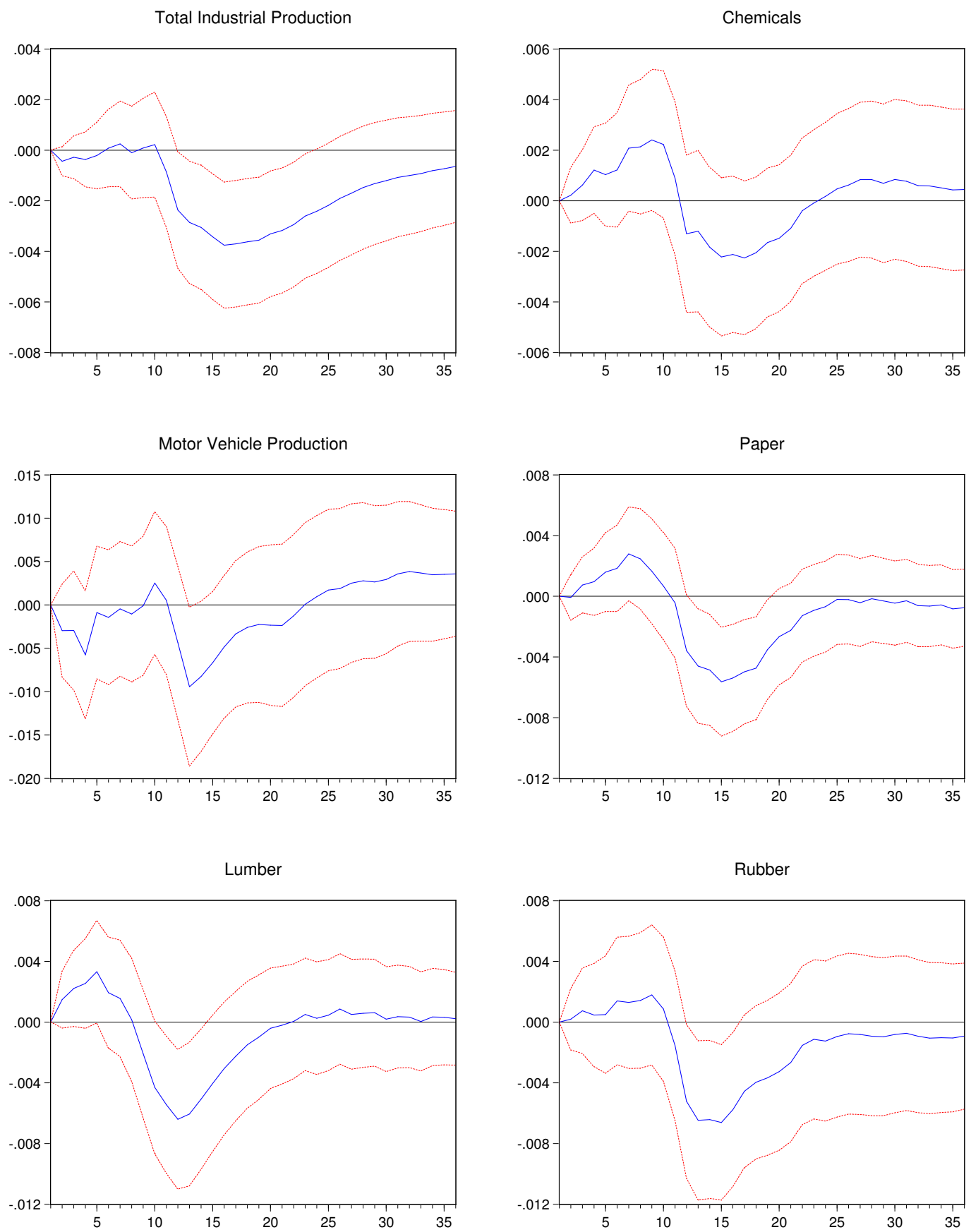
Figure 1: continued
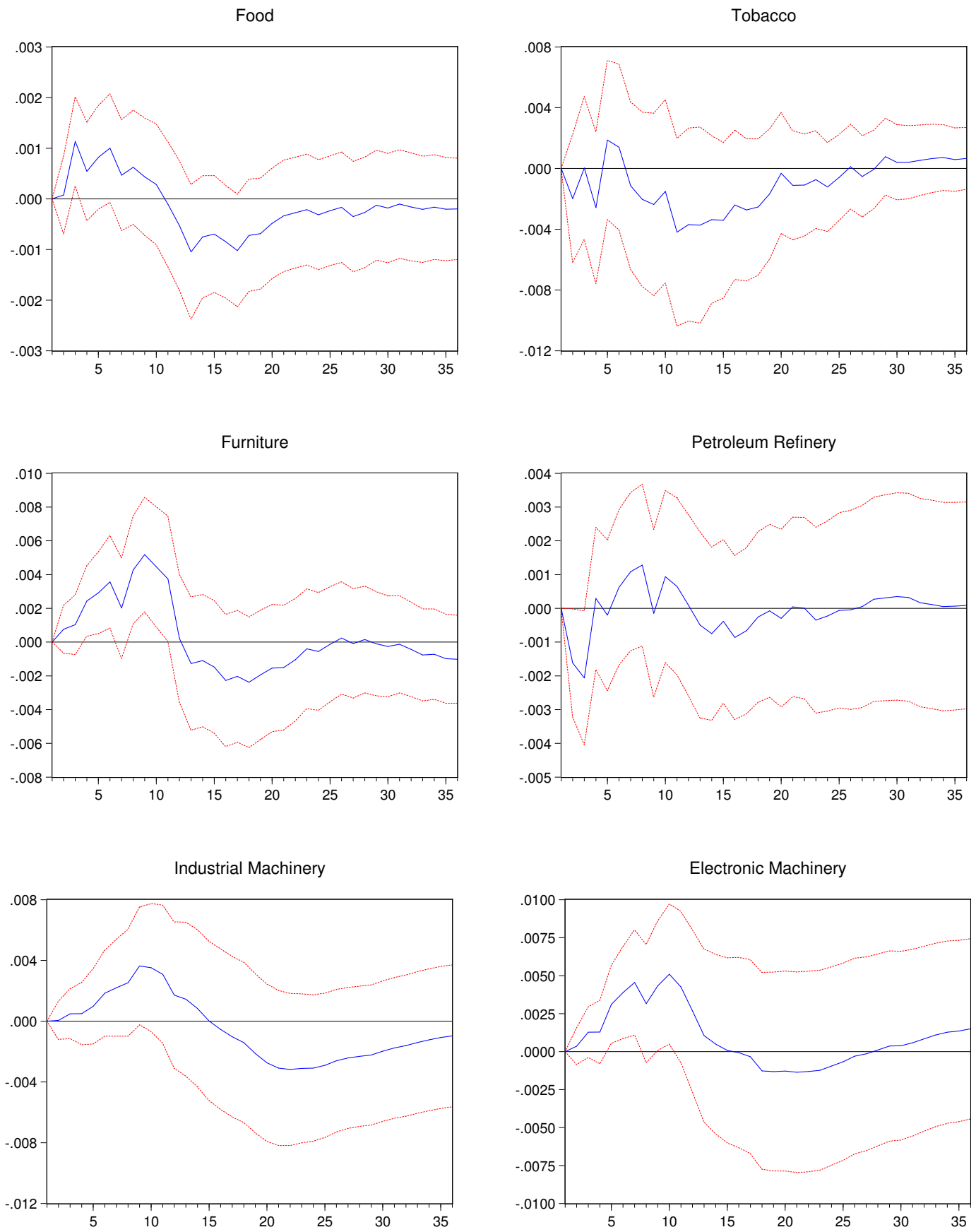
the relationship between the oil price and industrial production. The results are generally in line with the literature and the analysis shows that a characteristic pattern of the results emerges at both the aggregate and the industry-level. However, in order to make allowances to the discussion on this relationship's change, this full sample analysis needs to be extended. The following section's rolling impulse responses illustrate to what extent these characteristic full sample results depend on the sample period and whether there are differences regarding this across the 11 manufacturing industries.

\section{Rolling Impulse Responses}

Rolling impulse responses are used by Blanchard and Gali (2007) in order to capture the change in the oil price-macroeconomy relationship in a more gradual way. They, however, only estimate a number of bivariate VARs and investigate relationships between the oil price and variables such as consumer prices, GDP and employment. Blanchard and Gali (2007) argue that this restriction to bivariate models is necessary for estimating VARs with shorter sample periods. Their investigation of the oil price-GDP relationship shows that the strongest responses are found for samples beginning in the 1970s. They, however, only present point-estimates and do not discuss whether or not significant effects are present.

This paper uses monthly industrial production data as indicator of economic activity which, allows one - due to the larger number of observations - to estimate rolling impulse responses for higher-dimensional VARs. It, furthermore, investigates whether there are differences across a number of manufacturing industries. The particular focus is on the question to what extent the characteristic full sample results - no immediate impact, strong significant response 10-15 month after the shock, subsequent relaxation - can be accounted for by large oil shocks such as those associated with the first and second oil crises. Figure 2 presents the results. The left panels contain the responses' point estimates, the right panels the analytical upper twostandard-error band. ${ }^{10}$ The period axis denotes the begin of the subsamples,

\footnotetext{
${ }^{10}$ This study focusses on the question whether the negative responses are significant or
} 
the contour plots in the ground plane are two dimensional projections of the three dimensional impulse response surfaces. In the right panels, contours are plotted at the zero level only. Thus, the regions within the dashed blue lines are those areas where a significant effect of the oil price is found.

Inspecting the result for the total industrial production case shows immediately that the responses' pattern considerably change over time. What is more, this change appears to be fairly abrupt rather than gradual: only for subsamples beginning prior to 1975 the characteristic full sample results reappear. This becomes apparent from the "ditch" in the response surface and the significance regions in the contour plots. Once the early 1970s incidents are excluded from the sample, a considerably different pattern emerges: the responses appear to be weaker and to peak earlier after the shock. Only for a few samples beginning in the late 1970s and mid 1980s a negative significant effect is apparent, which, furthermore, is found already about 2 to 8 months after the shock. This result the full sample results did not suggest this effect appears to be superimposed by the first oil crisis.

Getting onto the industry-level, the general tendency of the total industrial production results recurs: the change in the relationship, the "1970s ditch", and the significance region's shifts. There are, however, some industryspecific differences. For industries such as motor vehicle production, chemicals, paper and lumber the "1970s ditch" is even more pronounced. A coherent significance region for the samples beginning prior to 1975, however, is only found for the paper industry. The lumber industry is similarly affected, but there are two separated significance regions. For the cases of the rubber industry as well as motor vehicle production, the 1980s significance regions appear to be more prominent - in contrast to the paper industry. The electronic machinery industry, finally, is only significantly affected in the very early, the furniture industry only in the more recent subsamples. These results the homogeneous full sample results did not suggest either and, thus, there are also industry-specifics that are superimposed by the first oil crisis. In accordance with the full sample results, however, the tobacco industry remains essentially unaffected.

not. Therefore, the lower error bands are not of interest. 
Figure 2: Rolling Impulse Responses

Total Industrial Production

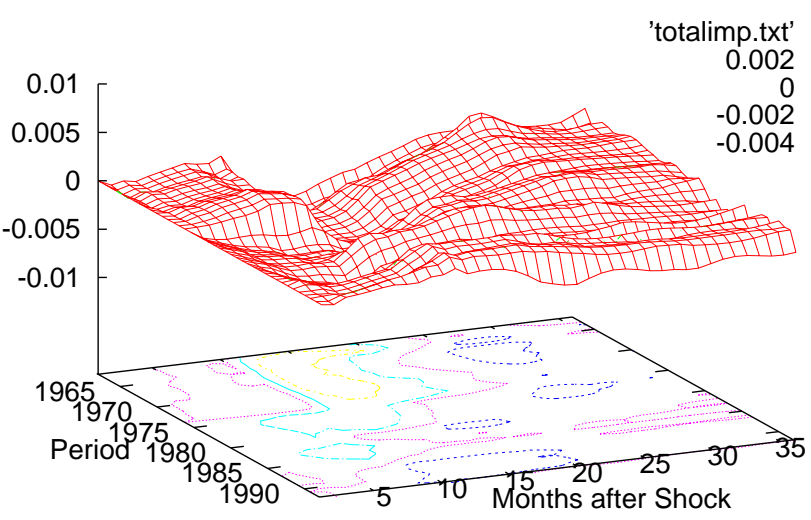

Chemicals

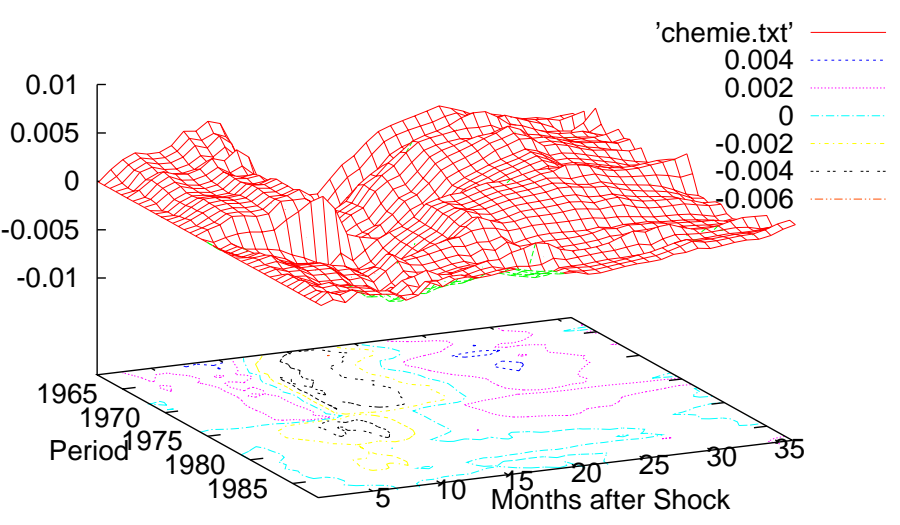

Motor Vehicle Production

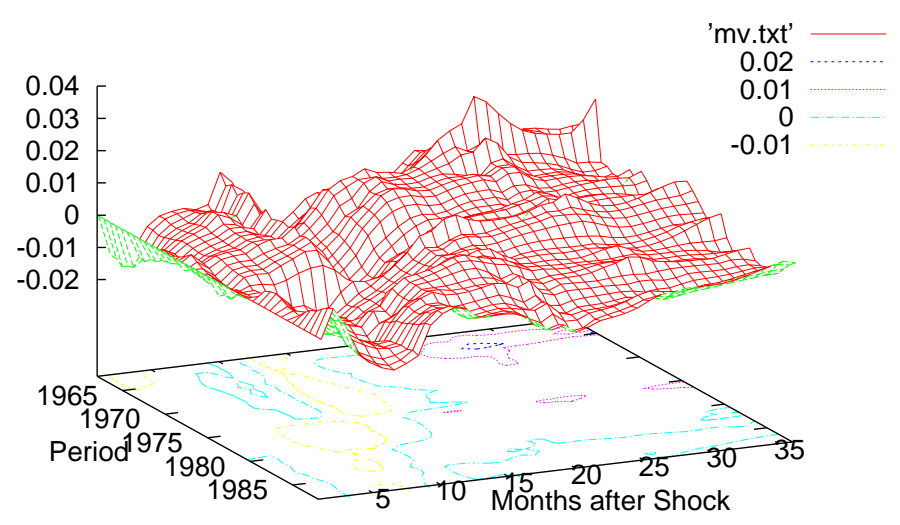

Upper Two-Standard-Error Band

'totalimp_se.txt'

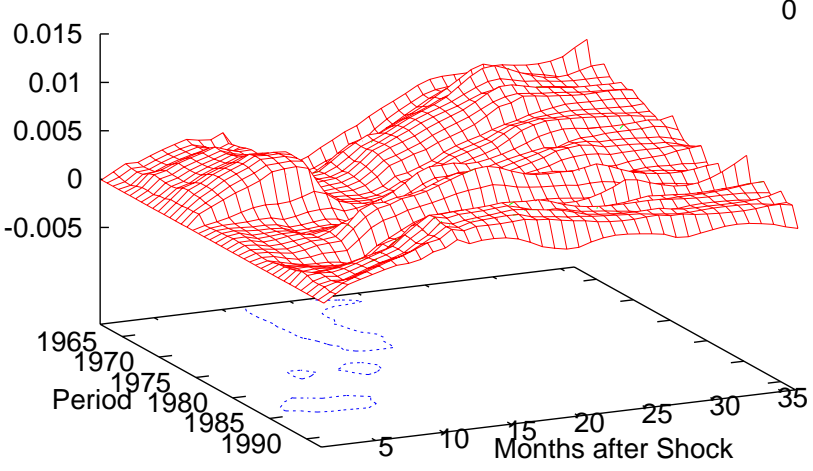

Upper Two-Standard-Error Band

'chemie_se.txt'

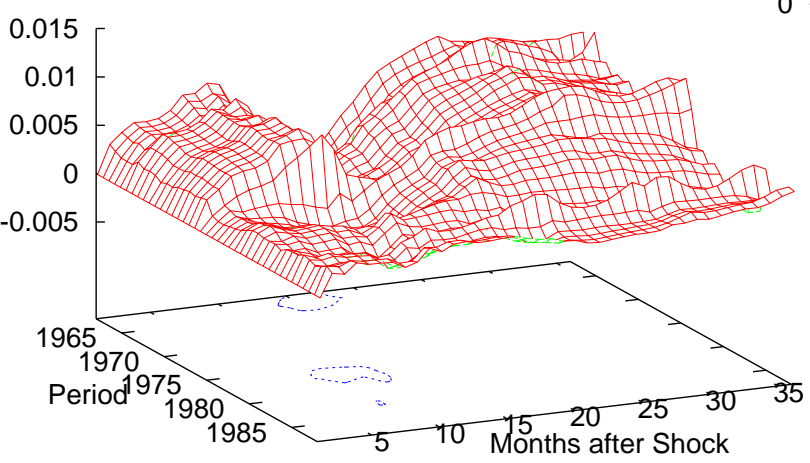

Upper Two-Standard-Error Band

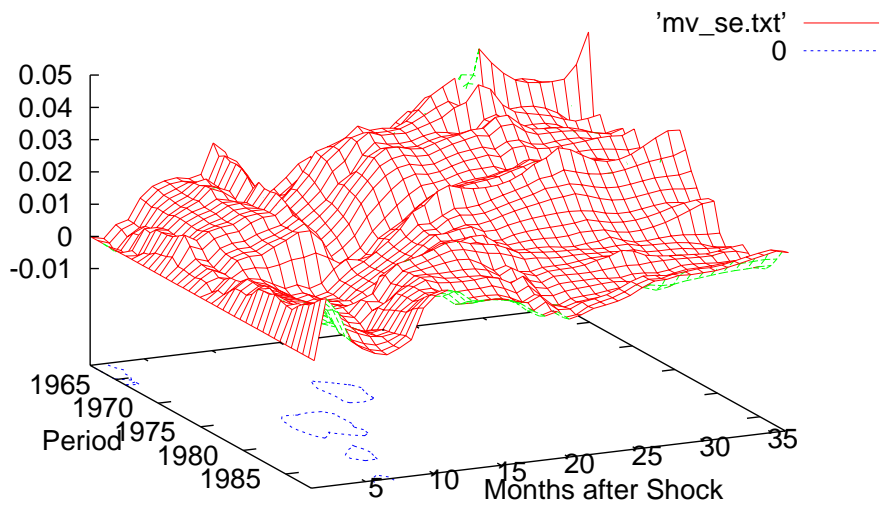


Figure 2: continued

Paper

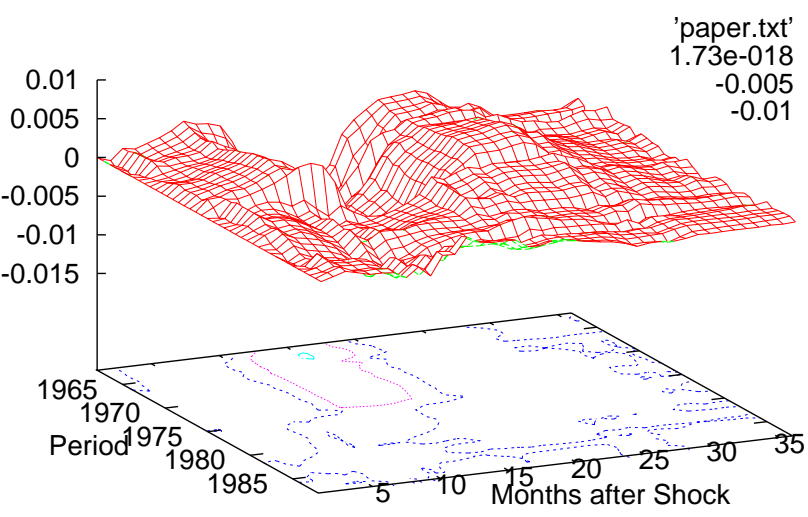

Lumber

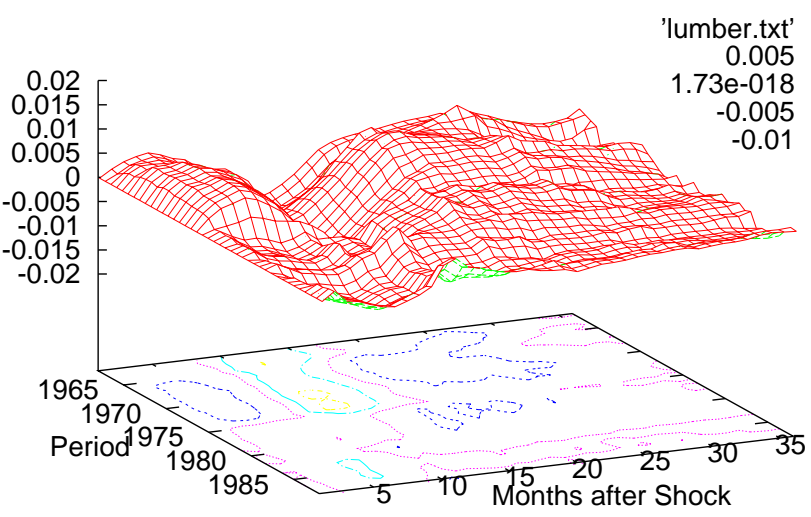

Rubber

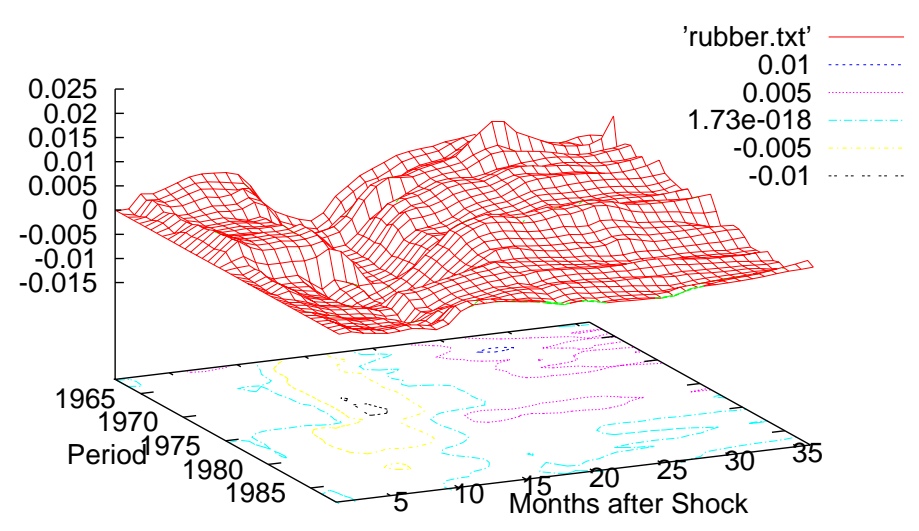

Upper Two-Standard-Error Band

'paper_se.txt'

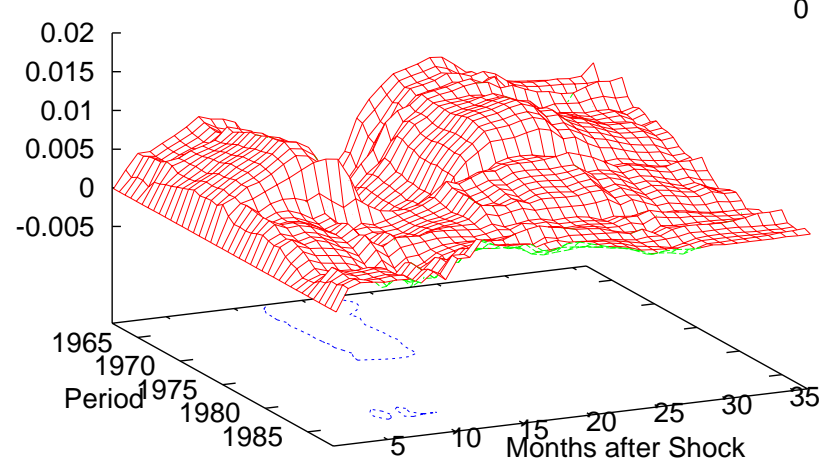

Upper Two-Standard-Error Band

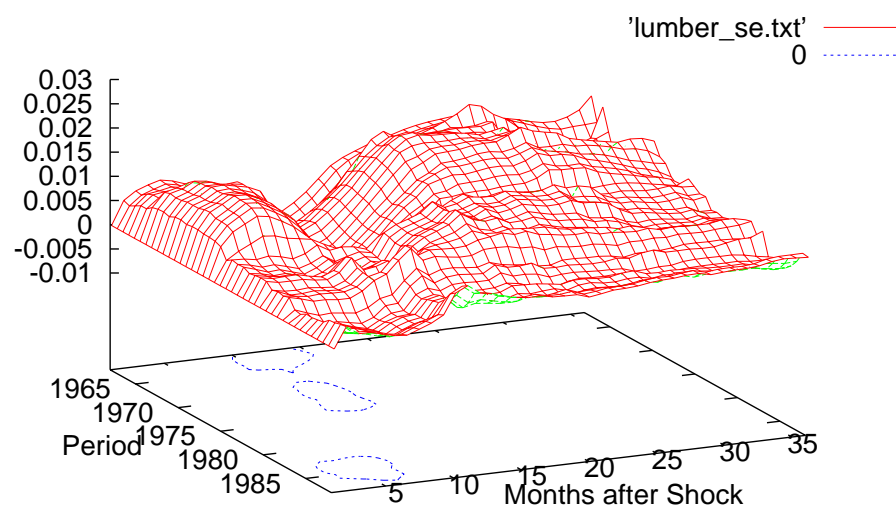

Upper Two-Standard-Error Band

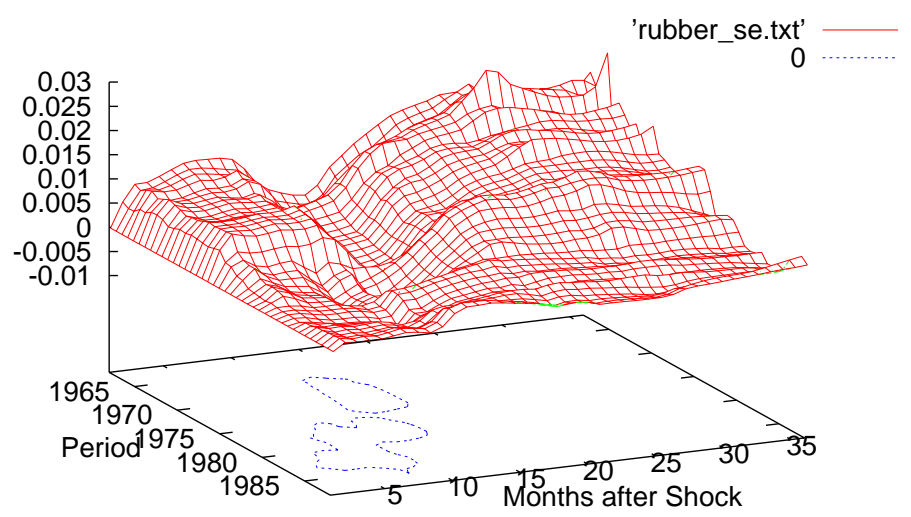


Figure 2: continued

Food

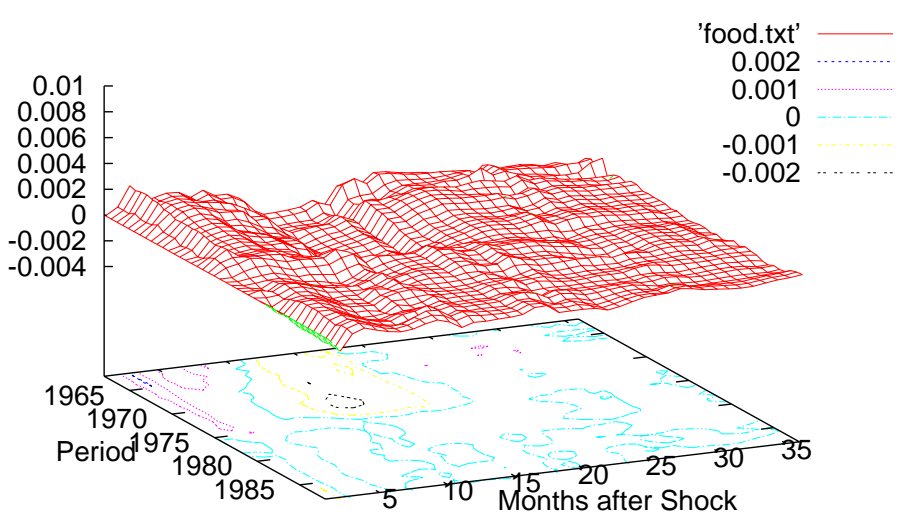

Tobacco

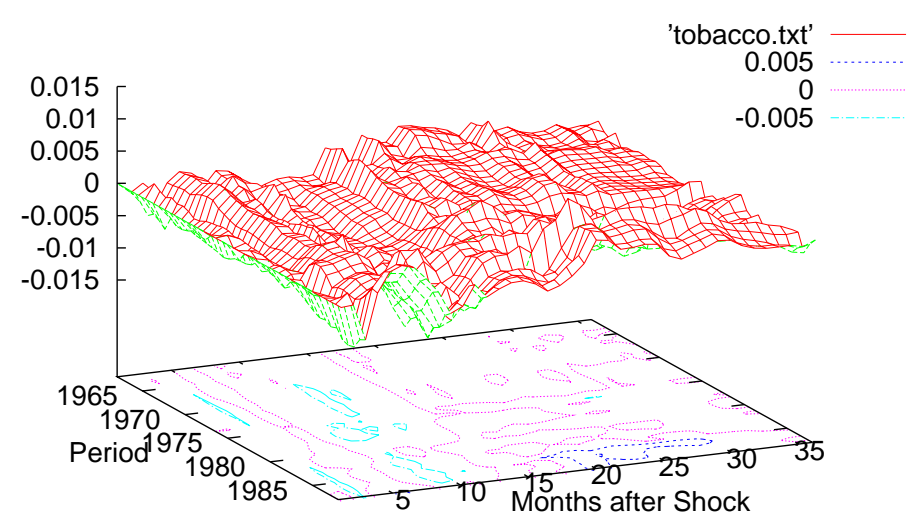

Furniture

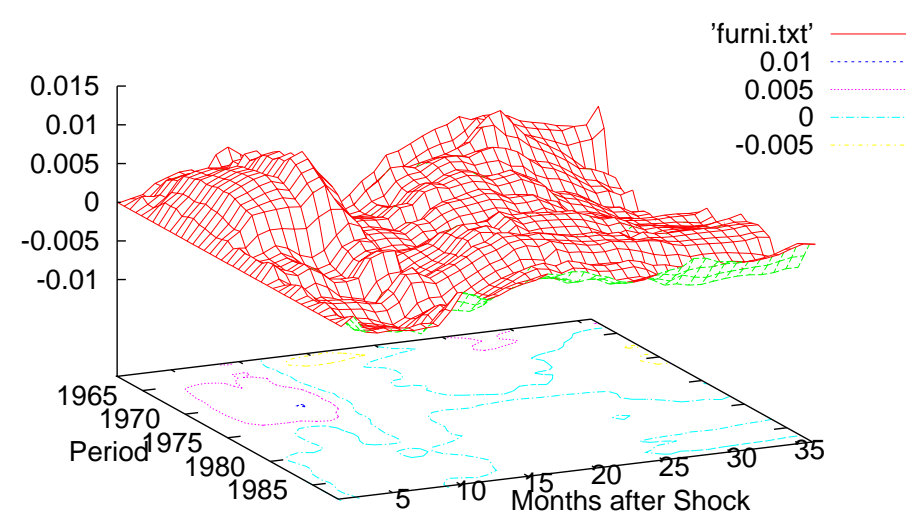

Upper Two-Standard-Error Band

'food_se.txt'

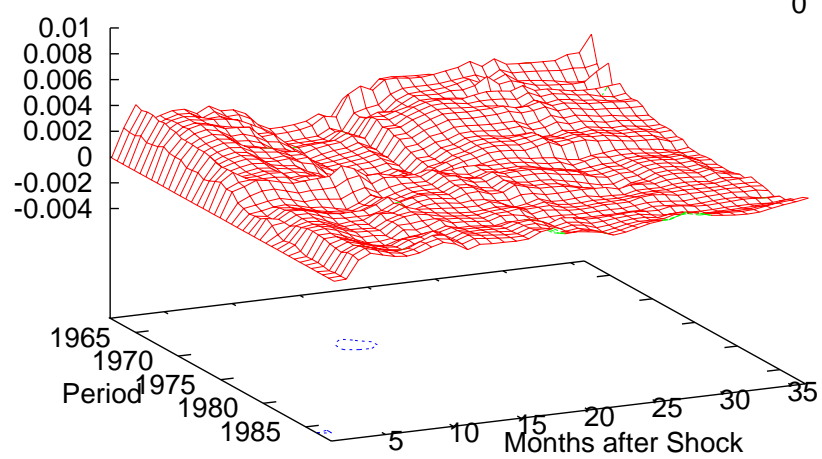

Upper Two-Standard-Error Band

'tobacco_se.txt'

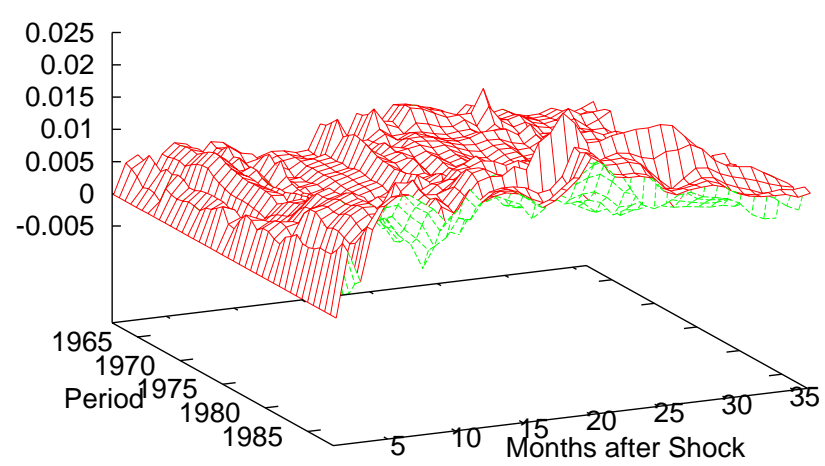

Upper Two-Standard-Error Band

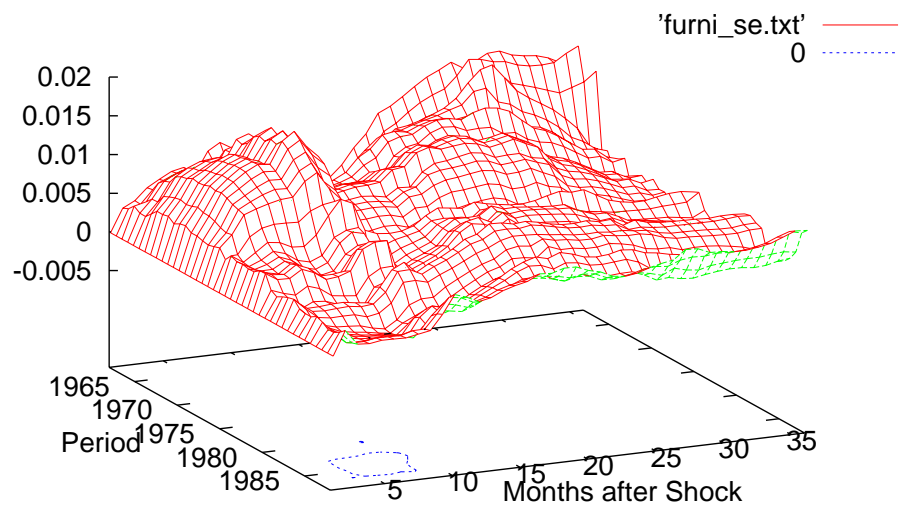


Figure 2: continued

Petroleum Refinery

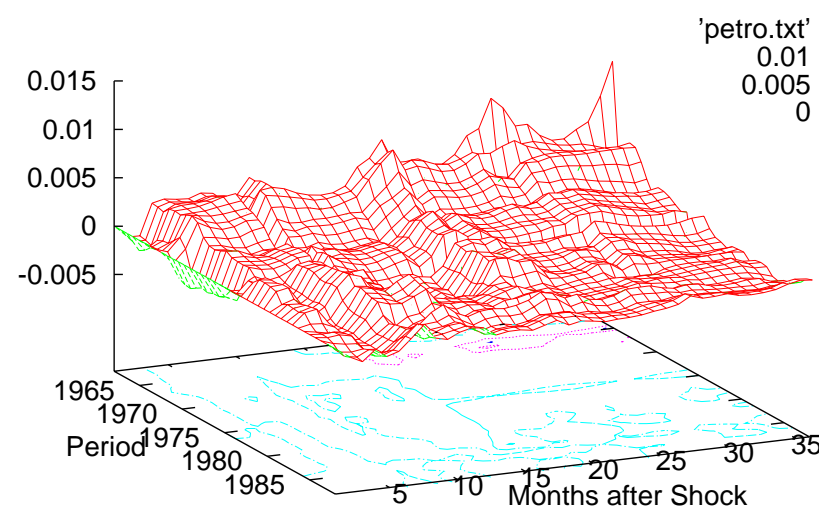

Industrial Machinery

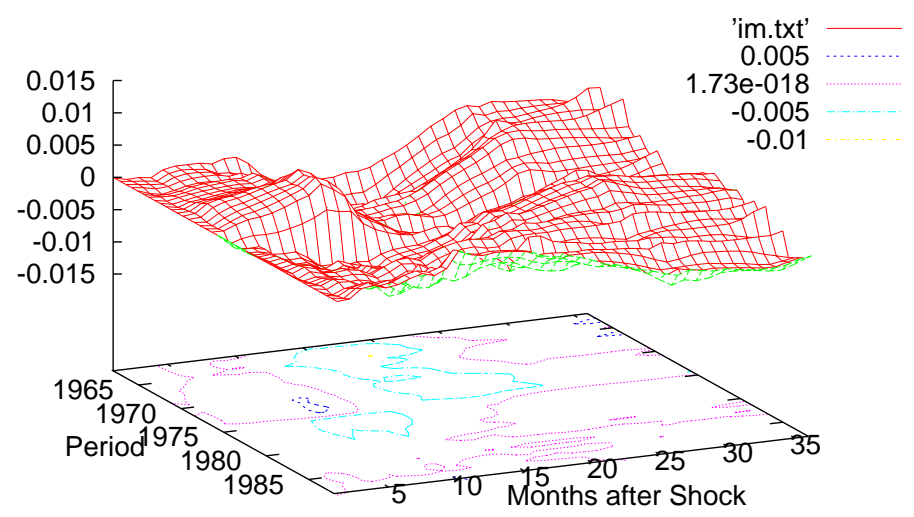

Electronic Machinery

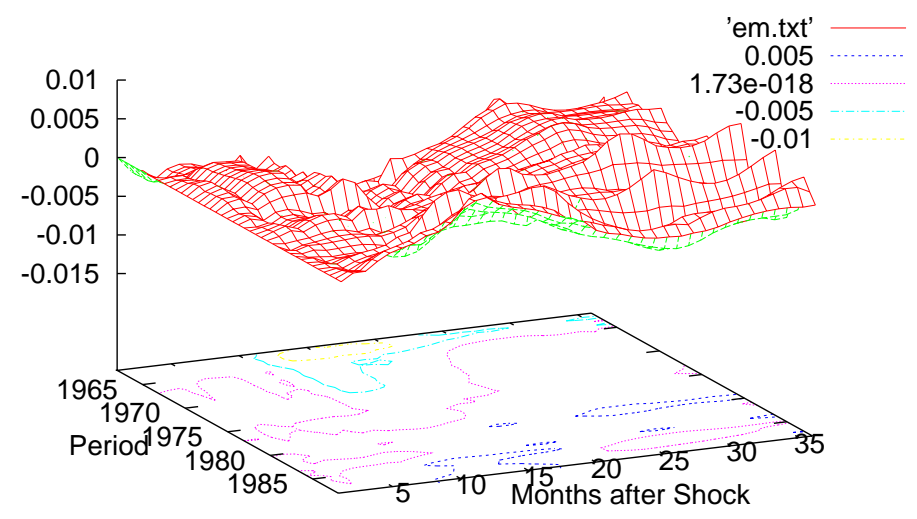

Upper Two-Standard-Error Band

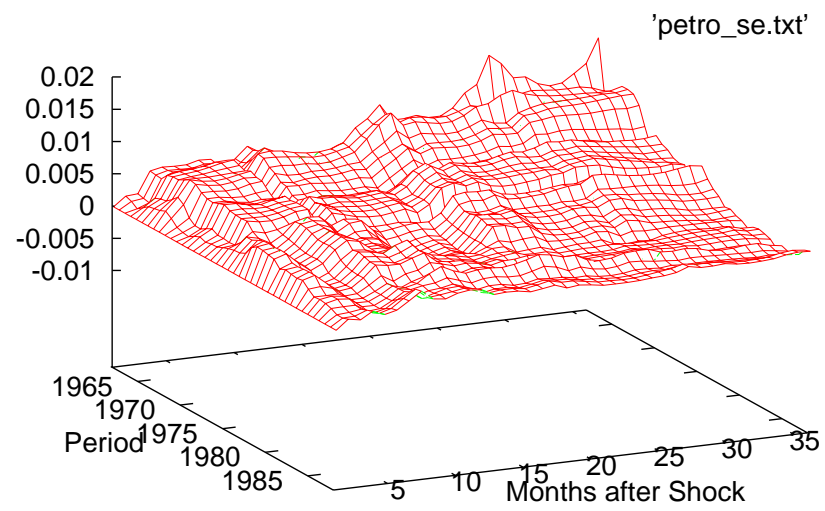

Upper Two-Standard-Error Band

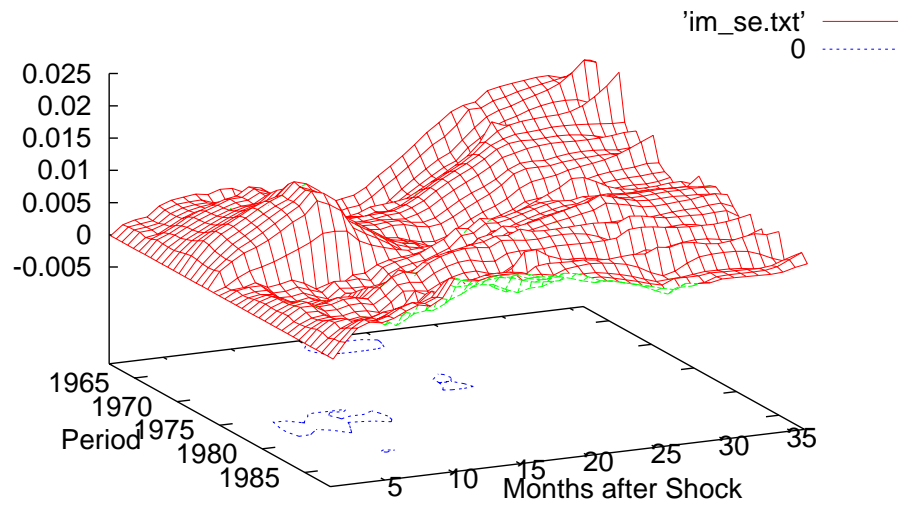

Upper Two-Standard-Error Band

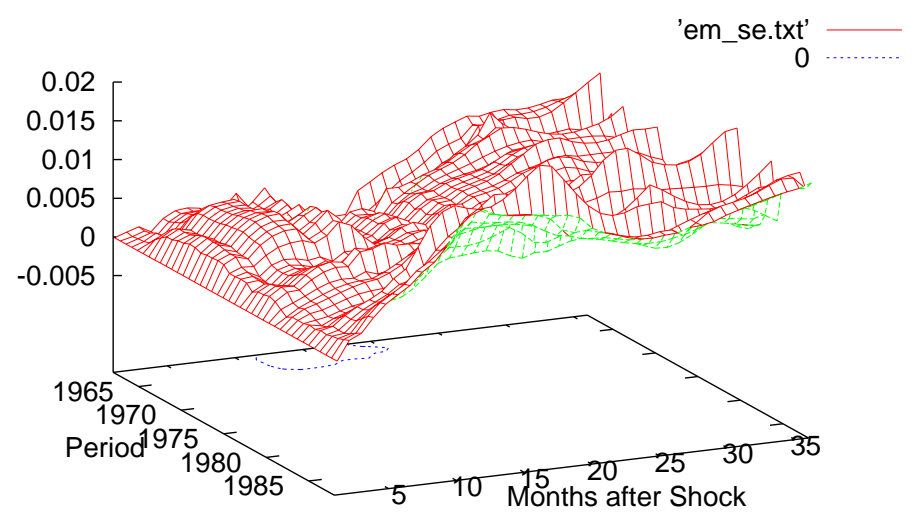


In a nutshell, the rolling impulse response technique employed here lends itself as to be used as it facilitates comparability of the results to those of other papers, allows for capturing also gradual changes and does not involve sophisticated structural break testing. The empirical result's contribution to the existing literature is twofold: they shed further light on, first, the discussion on the change in the oil price-macroeconomy nexus, and, second, on the factors explaining the Great Moderation.

Regarding the first, the finding of a considerable change in the relationship between the oil price and macroeconomic activity is confirmed. This change, however, appears to be abrupt rather than gradual. There are sufficient grounds for concluding that the 1970s oil shocks and the subsequent economic downturns still have a dominant impact on the results of standard empirical analyses. It has been shown that this study's full sample results - which are very similar to those of other recent studies - are largely attributable to the first oil crisis. The application of rolling impulse responses shows that once this incident is excluded from the sample, the pattern of the responses considerably changes. Moreover, some specific results of periods beginning around the mid 1980s could not have been anticipated from the full sample results - they are superimposed by the first oil crisis. Thus, in this sense this incident has "persistent" effects. Assuming that the strongest response of macroeconomic activity occurs about 1 year after the oil shocks, additionally, is fallacious and possibly leads to inappropriate policy measures. What is more, also important industry-specifics are superimposed by the first oil crisis. There are, however, a number of recent papers - Jimenez-Rodriguez and Sanchez (2005), Herrera (2006) and Huntington (2007) to name just a few - who certainly have novelty values such as the consideration of inventories, real income and more thorough cross-country comparisons, but employ standard empirical approaches that do not adequately account for the change in the oil price-macroeconomy nexus. Thus, it is not unlikely, that their results are also dominated by the 1970s and do not reflect the relationship in its current shape. In consequence, the empirical set-ups of these studies must be rethought.

Regarding the second, the Great Moderation, firstly discussed by Kim 
and Nelson (1999) and McConnell and Perez-Quiros (2000), finds three traditional explanations: first, improvements in inventory holding techniques [McConnell and Perez-Quiros, 2000], second, a better monetary policy [Clarida et al., 2000] and, third, "good luck" in the sense of the non-occurrence of adverse shocks to the economy [Stock and Watson, 2002]. Regarding the latter, recent papers such as Summers (2005) and Nakov and Pescatori (2008) argue that this "good luck" aspect can be accounted for by the non-occurrence of large oil shocks after the mid 1980s. This paper's results reinforce this argument. The rolling impulse responses show that the last subsamples with a significant impact of the oil price on industrial production begin around the mid 1980s. What is more, neither on the aggregate nor on the industry-level a significant effect is found for the most recent subsamples.

Two additional notions exist in the literature that need to be discussed now. First, Bernanke et al. (1997) promote the view that important effects of oil price shocks are attributable to bad monetary policy measures in response to an oil shock rather than the shock itself. Second, Kilian (2008) decomposes oil prices in oil supply shocks, aggregate demand shocks, and oil-market specific demand shocks and shows that these three shocks have considerably different impacts on real economic activity. The finding that the oil price surge witnessed after 2003 is driven by aggregate demand helps to explain why this surge did not cause a recession in the United States. In the same vein, Barsky and Kilian (2004) challenge a number of traditional notions and conclude that "disturbances in the oil market are likely to matter less for U.S. macroeconomic performance than has commonly been thought." It might be that there is an interaction between the size of the oil shocks focussed in this paper on the one hand and the shock's underlying cause and the role of monetary policy on the other. The abruptness of the change found in this study, however, suggests that the large oil price shocks are the culprit. ${ }^{11}$ The key findings of this paper, ultimately, remain unaffected even if there is a strong interaction: the first oil crisis still has a dominant impact on the long-run empirical results and the Great Moderation can still be accounted

\footnotetext{
${ }^{11}$ Moreover, Kilian's (2008) data start in 1975. Hence, the first oil crisis this paper focusses on is not included in his sample.
} 
for by the non-occurrence of large oil price shocks after the mid 1980s. In a way, these findings tally with those of Barsky and Kilian (2004): the oil price appears to have a considerably smaller impact than a number of recent papers still suggest. ${ }^{12}$

\section{Conclusions}

There is no doubt about the fact that the 1970s oil crises had a lasting effect on the economy. The increases' magnitude itself is still hard to match and, what is more, they took everybody completely unawares: the economy was marked by a fairly high share of oil, monetary authorities were forced to act ad-hoc, and firms and households needed to adjust their behavior in a considerably uncertain environment.

This, naturally, was a sublime concern for theoretical as well as empirical economists to investigate these dramatic incidents - Hamilton's (1983) seminal paper is considered a landmark in this literature. This and a larger number of subsequent empirical papers employ standard VAR models in order to capture this relationship. The fact that the relationship is not stable and easy to model, expressed by discussions regarding the functional form [Hamilton, 2003] and the proposal of various non-linear oil price measures [Hamilton, 1996; Lee and Ni, 1995], however, indicates that this task has proven to be more complicated than it originally appeared to be.

Recent evidence suggests, first, that the observed impact of oil price shocks is largely attributable to no fewer than three large oil price shocks - those associated to the first oil crisis 1973/74, the second oil crisis 1978/79 and the Gulf War 1990/91 [Gronwald, 2008]. Second, it is apparent that the relationship between the oil price and the macroeconomy has undergone a considerable change in the past few decades [Blanchard and Gali, 2007; Edelstein and Kilian, 2007]. Third, a newly established line of research considers the effects of oil price shocks also on the industry-level [Lee and Ni, 2002; Kilian and Park, 2008].

This paper contributes to the existing literature in two ways. It, first,

\footnotetext{
${ }^{12}$ See, for instance, Peersman and Van Robays (2009).
} 
reconsiders the change in the relationship between the oil price and macroeconomic activity by focussing on the large oil price surges mentioned above. Second, it tries to shed further light on the explanations of the so-called Great Moderation. It employs the innovative technique of rolling impulse responses in order to illustrate this change. Monthly industrial production data rather than quarterly GDP data as indicator of economic activity is used. This allows one - due to the larger number of observations - to estimate rolling impulse responses for higher-dimensional VARs. What is more, this approach facilitates comparability of the results to those of other papers and does not involve structural break testing.

The following key results emerge from this paper: first, the apparent change in the oil price-macroeconomy relationship appears to be abrupt rather than gradual and, what is more, is largely attributable to the first oil crisis. This incident still has a dominant impact on studies using frequently considered samples running from the 1960s to present - in particular the finding of the strongest response of economic activity one year after the oil shock's occurrence. Once this incident is removed from the sample, the pattern of the results considerably changes - in this sense the first oil crisis has "persistent" effects. The consideration of the industry-level, furthermore, shows that there are substantial differences across manufacturing industries. While industries such as paper are only significantly affected in early subsamples, motor vehicle production and the rubber industry show clearly different responses to oil price shocks and are only significantly affected in later subsamples. In a nutshell, both subsample and industry-specific results are superimposed.

Second, there is strong evidence that the "good luck" aspect of the Great Moderation can be accounted for by the non-occurrence of large oil shocks after the mid 1980s. The last subsamples where an significant effect of the oil price on industrial production is found begin around the mid 1980s. Thus, this paper reinforces views expressed by Summers (2005) and Nakov and Pescatori (2008). Fortune, however, is known to be fickle, which implies that relying on a forever-stable economy could be hazardous. The current financial crisis is a possible herald of an end of the Great Moderation. 
Thus, large oil price shocks can be regarded as very powerful in two ways. Their occurrence can cause severe economic crises and can affect results of empirical studies in surprisingly strong manner. Their non-occurrence, however, is able to move the economy to a regime of remarkable tranquility.

\section{ACKNOWLEDGEMENTS}

The author gratefully acknowledges valuable comments by Lutz Kilian as well as technical support by Gabriel Ahlfeldt.

\section{REFERENCES}

Baumeister, C. and G. Peersman (2008). "Time Varying Effects of Oil Supply Shocks on the US Economy", available at

SSRN : http://ssrn.com/abstract=1093702

BARsky, R.B. AND L.KILIAN (2004). "Oil and the Macroeconomy since the 1970s", Journal of Economic Perspectives 18: 115-134

Bernanke, B.S. (1983). "Irreversibility, uncertainty, and cyclical investment", Quarterly Journal of Economics: 85-106

Bernanke, B.S., M. Gertler and M. Watson (1997). "Systematic Monetary Policy and the Effects of Oil Price Shocks", Brookings Papers on Economic Activity: Vol. 1997, No.1 (1997): 91-157

Blanchard, O.J. and J. Gali (2007). "The Macroeconomic Effects of Oil Shocks: Why are the 2000s so different from the 1970s?", NBER Working Paper 13368

Bohi, D.R. (1989). "Energy Price Shocks and Macroeconomic Performance", Resources for the Future, Washington D.C.

BoHI, D.R. (1991). "On the Macroeconomic Effects of Energy Price Shocks", Resources and Energy 13:145-162

Burbidge, J. And A. Harrison (1984). "Testing for the Effects of Oil-Price Rises using Vector Autoregressions", International Economic Review 25: 459-484

Clarida, R., J. Gali and M. Gertler (2000). "Monetary Policy Rules and Macroeconomic Stability: Evidence and some Theory", Quarterly Journal of Economics 115: $147-180$ 
Edelstein, P. And L. Kilian (2007). "The Response of Business Fixed Investment to Changes in Energy Prices: A Test of Some Hypotheses about the Transmission of Energy Price Shocks", The B.E. Journal of Macroeconomics 7 (contributions)

Freeman, S.L., M.J. Niefer and J.M. Roop (1997). "Measuring Industrial Energy Intesity: Practical Issues and Problems", Energy Policy 25: 703-714

Gronwald, M. (2008). "Large Oil Shocks and the U.S. Economy: Infrequent Incidents with Large Effects", The Energy Journal 29: 151-170

Hamilton, J.D. (1983). "Oil and the Macroeconomy since World War II", The Journal of Political Economy 91: 228-248

Hamilton, J.D. (1988). "A Neoclassical Model of Unemployment and the Business Cycle", The Journal of Political Economy 96: 593-617

Hamilton, J.D. (1996). "This is What Happened to the Oil Price-Macroeconomy Relationship", Journal of Monetary Economics 38: 215-220

Hamilton, J.D. (2003). "What is an Oil Shock?", Journal of Econometrics 113: 363398

Herrera, A.M. (2006). "Oil Price Shocks and Macroeconomic Dynamics: The Role of Inventories", available at https://www.msu.edu/ herrer20/documents/HFebruary2006.pdf

Herrera, A.M. and E.Pesavento (2007). "Oil Price Shocks, Systematic Monetary Policy and the "Great Moderation"', Macroeconomic Dynamics forthcoming

Hooker, M.A. (1996). "What Happened to the Oil Price-Macroeconomy Relationship?", Journal of Monetary Economics 38: 195-213

Huntington, H.G. (2007). "Oil Shocks and U.S. Real Income", The Energy Journal 28(4): $31-46$

Jimenez-Rodrgiuez, R. And M. Sanchez (2005). "Oil Price Shocks and Real GDP Growth, Empirical Evidence For Some OECD Countries", Applied Economics 37: $201-228$

Jimenez-RodRiguez, R. (2007). "The Industrial Impact of Oil Price Shocks: Evidence from the Industries of six OECD Countries", Documentos de Trabajo No 0731, Banco de Espana

Jones, D.W., P.N. Leiby And I.K.Paik (2004). "Oil Price Shocks and the Macroeconomy: What has been learned since 1996", The Energy Journal 25, 1-32

Kilian, L. (2008). "Not all Oil Price Shocks are Alike: Disentangling Demand and Supply Shocks in the Crude Oil Market", American Economic Review, forthcoming 
Kilian, L. And C. Park (2008). "The Impact of Oil Price Shocks on the U.S. Stock Market", International Economic Review, forthcoming

Kim, C.J. and C.R. Nelson (1999). "Has the U.S. Economy become more stable? A Bayesian Approach Based on a Markov-Switching Model of Business Cycle", Review of Economics and Statistics 81: 608-616

Lee, K., S. Ni and R. Ratti (1995). "Oil Shocks and the Macroeconomy: the Role of Price Variability", The Energy Journal 16: 39-56

Lee, K. And S. Ni (2002). "On the Dynamic Effects of Oil Price Shocks: A Study Using Industry Level Data", Journal of Monetary Economics 49: 823-852

Lilien, D. (1982). "Sectoral Shifts and Cyclical Unemployment", The Journal of Political Economy 90: 777-793

Liu, N. And Ang, B.W. (2007). "Factors Shaping Aggregate Energy Intensity Trend for Industry: Energy Intensity versus Product Mix", Energy Economics 29: 609-635

McConnell, M.M. and G. Perez-Quiros (2000). "Output Fluctuations in the United States: What has changed since the early 1980s?", American Economic Review 90: 1464-1476

Nakov, A. and A. Pescatori (2008). "Oil and the Great Moderation", The Economic Journal, forthcoming

Peersman, G. and I. Van Robays (2009). "Oil and the Euro Area Economy", available at

http://www.feb.ugent.be/Fineco/gert/documents/

Peersman_Van_Robays_EP_december2008.pdf

Rogoff, K. (2006). "Oil and the Global Economy", available at http://www.nes.ru/public-presentations/Papers/

0il\%20and\%20the\%20Global\%20Economy_Rogoff__v2.pdf

Rotemberg, J.J. And M. Woodford (1995). "Imperfect Competition and the Effect of Energy Price Increases on Economic Activity", Journal of Money, Credit and Banking 28(4), Part 1: 549-577

Sims, C.A. (1980). "Macroeconomics and Reality", Econometrica 48: 1-47

Stock, J.H. And M. Watson (2002). "Has the Business Cycle changed and why?", in: Gertler, M. and K. Rogoff (eds.), NBER Macroeconomics Annual 2002, 159218, Cambridge and London: MIT Press

Summers, P.M. (2005). "What caused the Great Moderation? Some Cross-Country Evidence", Economic Review, Federal Reserve Bank of Kansas City (Q III): 5-32 


\section{A Appendix: Alternative Specifications}

This appendix provides aggregate-level rolling impulse responses for a number of alternative specifications: first, different orderings of the variables in the VAR (upper and middle panel of Figure 3), and, second, using the 3-yearvariant of Hamilton's (1996) oil price specification (lower panel of Figure 3). The two alternative variable orderings represent more exogenous rankings of the oil price variable. Alternative ordering I: short-term interest rate, long-term interest rate, oil price, M2 money supply, industrial production and consumer price index; alternative ordering II: oil price, industrial production, M2 money supply, short-term interest rate, long-term interest rate, consumer price index. It is evident the the general pattern of the results remains essentially unchanged. 
Figure 3: Rolling Impulse Responses, Alternative Specifications

Total Industrial Production, Alternative Specification I

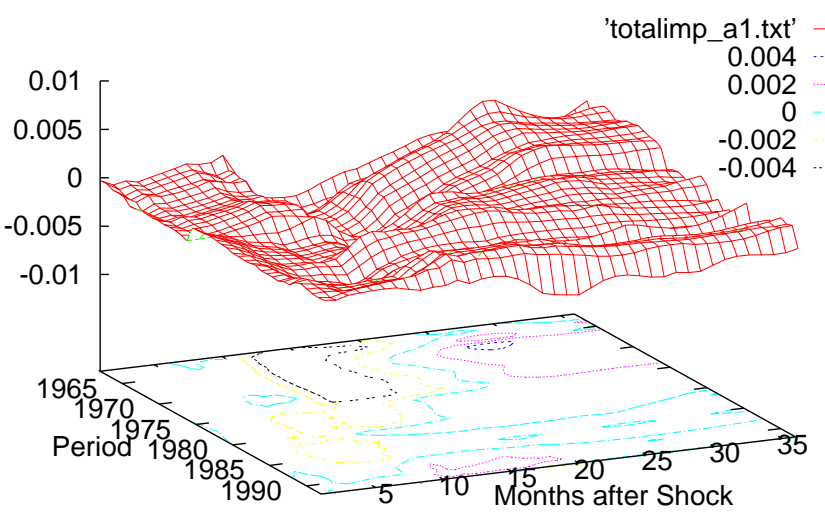

Total Industrial Production, Alternative Specification II

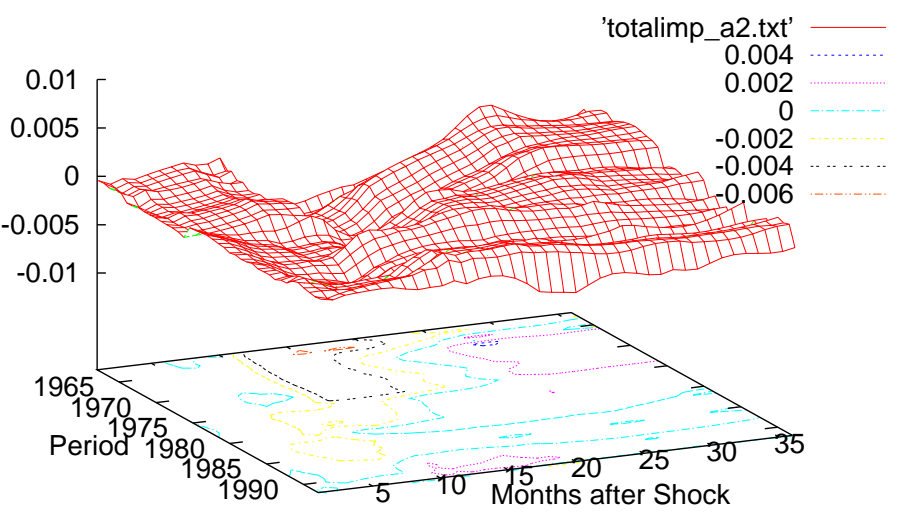

Total Industrial Production, 3-Year Oil Price Specification

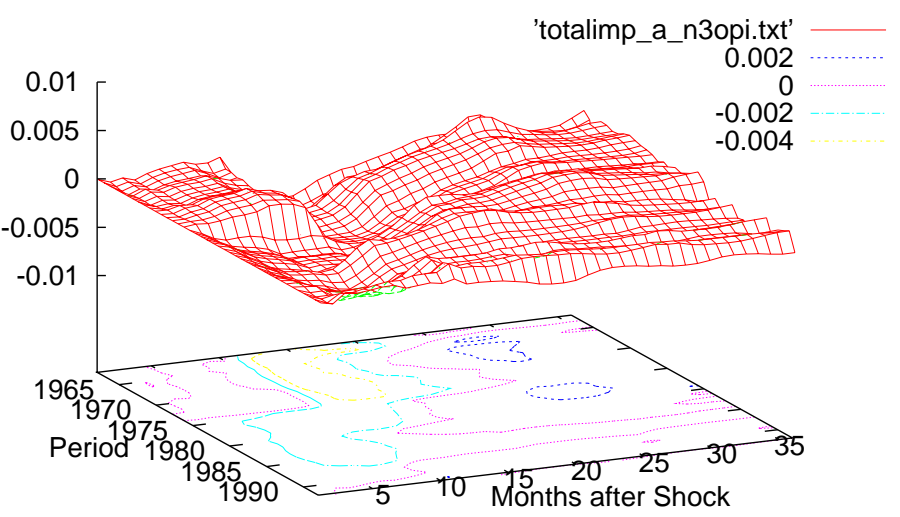

Upper Two-Standard-Error Band

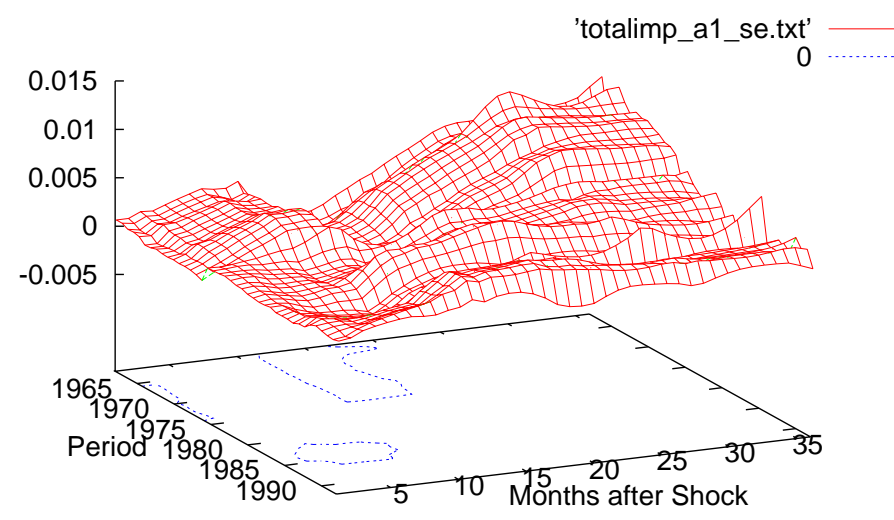

Upper Two-Standard-Error Band

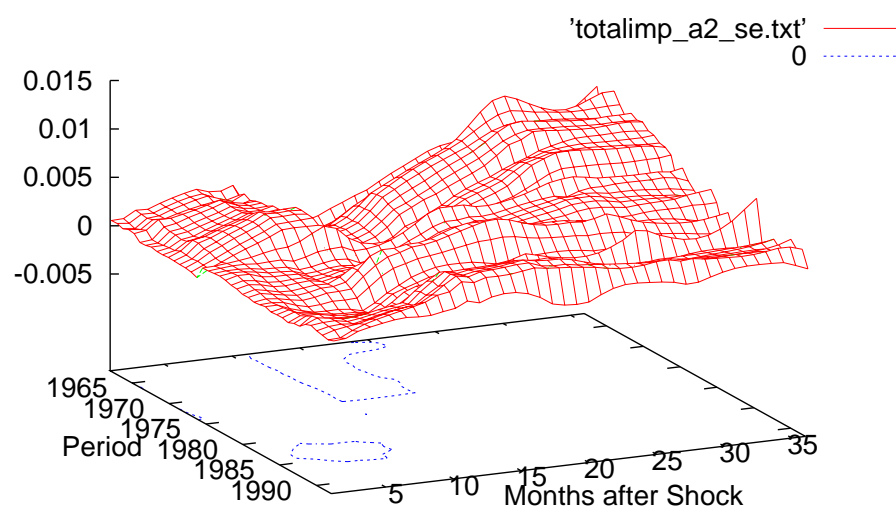

Upper Two-Standard-Error Band

'totalimp_a_n3opi_se.txt'

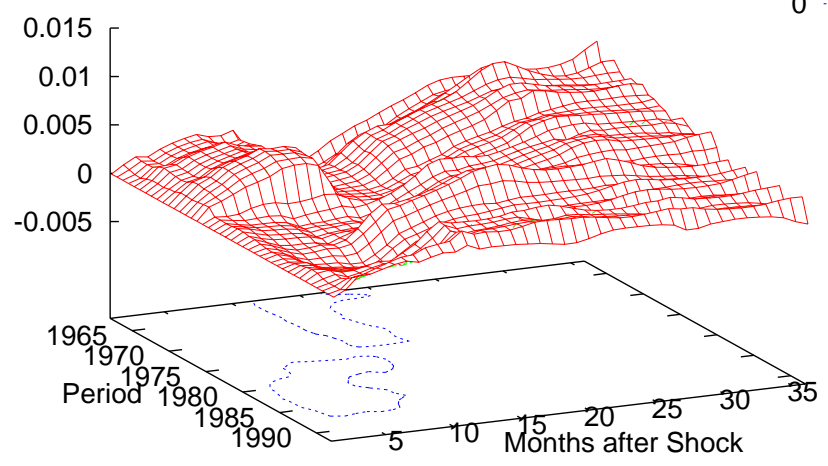




\section{CESifo Working Paper Series}

for full list see www.cesifo-group.org/wp

(address: Poschingerstr. 5, 81679 Munich, Germany, office@cesifo.de)

2641 Martin Halla, Mario Lackner and Friedrich G. Schneider, An Empirical Analysis of the Dynamics of the Welfare State: The Case of Benefit Morale, May 2009

2642 Balázs Égert, Infrastructure Investment in Network Industries: The Role of Incentive Regulation and Regulatory Independence, May 2009

2643 Christian Gollier, Expected Net Present Value, Expected Net Future Value, and the Ramsey Rule, May 2009

2644 Sören Blomquist and Håkan Selin, Hourly Wage Rate and Taxable Labor Income Responsiveness to Changes in Marginal Tax Rates, May 2009

2645 Dominique Demougin, Oliver Fabel and Christian Thomann, Implicit vs. Explicit Incentives: Theory and a Case Study, May 2009

2646 Francesco C. Billari and Vincenzo Galasso, What Explains Fertility? Evidence from Italian Pension Reforms, May 2009

2647 Kjell Arne Brekke, Karen Evelyn Hauge, Jo Thori Lind and Karine Nyborg, Playing with the Good Guys - A Public Good Game with Endogenous Group Formation, May 2009

2648 Guglielmo Maria Caporale and Luis A. Gil-Alana, Multi-Factor Gegenbauer Processes and European Inflation Rates, May 2009

2649 Henning Bohn, A Static Model for Voting on Social Security, May 2009

2650 Markus Haavio and Kaisa Kotakorpi, The Political Economy of Sin Taxes, May 2009

2651 Augusto de la Torre, María Soledad Martínez Pería and Sergio L. Schmukler, Drivers and Obstacles to Banking SMEs: The Role of Competition and the Institutional Framework, May 2009

2652 Tobias Lindhe and Jan Södersten, Dividend Taxation, Share Repurchases and the Equity Trap, May 2009

2653 Assaf Razin and Edith Sand, Migration-Regime Liberalization and Social Security: Political-Economy Effect, May 2009

2654 Yin-Wong Cheung and Hiro Ito, A Cross-Country Empirical Analysis of International Reserves, May 2009

2655 Bart Cockx and Bruno Van der Linden, Flexicurity in Belgium. A Proposal Based on Economic Principles, May 2009 
2656 Michael Melvin, Lukas Menkhoff and Maik Schmeling, Exchange Rate Management in Emerging Markets: Intervention via an Electronic Limit Order Book, May 2009

2657 Susanne Neckermann, Reto Cueni and Bruno S. Frey, What is an Award Worth? An Econometric Assessment of the Impact of Awards on Employee Performance, May 2009

2658 Steven Brakman, Harry Garretsen and Charles van Marrewijk, Economic Geography within and between European Nations: The Role of Market Potential and Density across Space and Time, May 2009

2659 Giovanni Facchini and Cecilia Testa, Reforming Legislatures: Is one House better than two?, May 2009

2660 Carsten Kowalczyk and Raymond Riezman, Trade Agreements, May 2009

2661 Oliver Falck, Stephan Heblich and Elke Luedemann, Identity and Entrepreneurship, May 2009

2662 Christian Lessmann and Gunther Markwardt, One Size Fits All? Decentralization, Corruption, and the Monitoring of Bureaucrats, May 2009

2663 Felix Bierbrauer, On the Legitimacy of Coercion for the Financing of Public Goods, May 2009

2664 Alessandro Cigno, Agency in Family Policy: A Survey, May 2009

2665 Claudia M. Buch and Christian Pierdzioch, Low Skill but High Volatility?, May 2009

2666 Hendrik Jürges, Kerstin Schneider, Martin Senkbeil and Claus H. Carstensen, Assessment Drives Learning: The Effect of Central Exit Exams on Curricular Knowledge and Mathematical Literacy, June 2009

2667 Eric A. Hanushek and Ludger Woessmann, Schooling, Cognitive Skills, and the Latin American Growth Puzzle, June 2009

2668 Ourania Karakosta, Christos Kotsogiannis and Miguel-Angel Lopez-Garcia, Does Indirect Tax Harmonization Deliver Pareto Improvements in the Presence of Global Public Goods?, June 2009

2669 Aleksandra Riedl and Silvia Rocha-Akis, Testing the Tax Competition Theory: How Elastic are National Tax Bases in OECD Countries?, June 2009

2670 Dominique Demougin and Carsten Helm, Incentive Contracts and Efficient Unemployment Benefits, June 2009

2671 Guglielmo Maria Caporale and Luis A. Gil-Alana, Long Memory in US Real Output per Capita, June 2009 
2672 Jim Malley and Ulrich Woitek, Productivity Shocks and Aggregate Cycles in an Estimated Endogenous Growth Model, June 2009

2673 Vivek Ghosal, Business Strategy and Firm Reorganization under Changing Market Conditions, June 2009

2674 Francesco Menoncin and Paolo M. Panteghini, Retrospective Capital Gains Taxation in the Real World, June 2009

2675 Thomas Hemmelgarn and Gaëtan Nicodème, Tax Co-ordination in Europe: Assessing the First Years of the EU-Savings Taxation Directive, June 2009

2676 Oliver Himmler, The Effects of School Competition on Academic Achievement and Grading Standards, June 2009

2677 Rolf Golombek and Michael Hoel, International Cooperation on Climate-Friendly Technologies, June 2009

2678 Martin Cave and Matthew Corkery, Regulation and Barriers to Trade in Telecommunications Services in the European Union, June 2009

2679 Costas Arkolakis, A Unified Theory of Firm Selection and Growth, June 2009

2680 Michelle R. Garfinkel, Stergios Skaperdas and Constantinos Syropoulos, International Trade and Transnational Insecurity: How Comparative Advantage and Power are Jointly Determined, June 2009

2681 Marcelo Resende, Capital Structure and Regulation in U.S. Local Telephony: An Exploratory Econometric Study; June 2009

2682 Marc Gronwald and Janina Ketterer, Evaluating Emission Trading as a Policy Tool Evidence from Conditional Jump Models, June 2009

2683 Stephan O. Hornig, Horst Rottmann and Rüdiger Wapler, Information Asymmetry, Education Signals and the Case of Ethnic and Native Germans, June 2009

2684 Benoit Dostie and Rajshri Jayaraman, The Effect of Adversity on Process Innovations and Managerial Incentives, June 2009

2685 Peter Egger, Christian Keuschnigg and Hannes Winner, Incorporation and Taxation: Theory and Firm-level Evidence, June 2009

2686 Chrysovalantou Milliou and Emmanuel Petrakis, Timing of Technology Adoption and Product Market Competition, June 2009

2687 Hans Degryse, Frank de Jong and Jérémie Lefebvre, An Empirical Analysis of Legal Insider Trading in the Netherlands, June 2009

2688 Subhasish M. Chowdhury, Dan Kovenock and Roman M. Sheremeta, An Experimental Investigation of Colonel Blotto Games, June 2009 
2689 Alexander Chudik, M. Hashem Pesaran and Elisa Tosetti, Weak and Strong Cross Section Dependence and Estimation of Large Panels, June 2009

2690 Mohamed El Hedi Arouri and Christophe Rault, On the Influence of Oil Prices on Stock Markets: Evidence from Panel Analysis in GCC Countries, June 2009

2691 Lars P. Feld and Christoph A. Schaltegger, Political Stability and Fiscal Policy - Time Series Evidence for the Swiss Federal Level since 1849, June 2009

2692 Michael Funke and Marc Gronwald, A Convex Hull Approach to Counterfactual Analysis of Trade Openness and Growth, June 2009

2693 Patricia Funk and Christina Gathmann, Does Direct Democracy Reduce the Size of Government? New Evidence from Historical Data, 1890-2000, June 2009

2694 Kirsten Wandschneider and Nikolaus Wolf, Shooting on a Moving Target: Explaining European Bank Rates during the Interwar Period, June 2009

2695 J. Atsu Amegashie, Third-Party Intervention in Conflicts and the Indirect Samaritan's Dilemma, June 2009

2696 Enrico Spolaore and Romain Wacziarg, War and Relatedness, June 2009

2697 Steven Brakman, Charles van Marrewijk and Arjen van Witteloostuijn, Market Liberalization in the European Natural Gas Market - the Importance of Capacity Constraints and Efficiency Differences, July 2009

2698 Huifang Tian, John Whalley and Yuezhou Cai, Trade Sanctions, Financial Transfers and BRIC's Participation in Global Climate Change Negotiations, July 2009

2699 Axel Dreher and Justina A. V. Fischer, Government Decentralization as a Disincentive for Transnational Terror? An Empirical Analysis, July 2009

2700 Balázs Égert, Tomasz Koźluk and Douglas Sutherland, Infrastructure and Growth: Empirical Evidence, July 2009

2701 Felix Bierbrauer, Optimal Income Taxation and Public Goods Provision in a Large Economy with Aggregate Uncertainty, July 2009

2702 Marc Gronwald, Investigating the U.S. Oil-Macroeconomy Nexus using Rolling Impulse Responses, July 2009 